\title{
Suicide Motives in Russian and European Literary Tradition
}

\author{
Nikolai I. Nikolaev ${ }^{1} \&$ Tatiana V. Shvetsova ${ }^{1}$ \\ ${ }^{1}$ Northern (Arctic) Federal University named after M. V. Lomonosov (NArFU), Severodvinsk, Russia \\ Correspondence: Tatiana V. Shvetsova, Northern (Arctic) Federal University named after M.V. Lomonosov \\ (NArFU), captain Voronin Street, 6, Archangel region, 164500 Severodvinsk, Russia. E-mail: tavash@yandex.ru
}

\author{
Received: October 26, 2014 Accepted: December 13, 2014 Online Published: February 12, 2015 \\ doi:10.5539/ass.v11n5p344 URL: http://dx.doi.org/10.5539/ass.v11n5p344
}

\begin{abstract}
The purpose of this article is to identify the underlying implications and motives of suicide of Russian literary characters of the classical era against the backdrop of Western European literary tradition. After analyzing the issue concerning the diversity of the suicide motives of heroines in Turgenev's novelettes ("L'Antchar", "An Unhappy Girl", and "Klara Milich"), we came to the conclusion that the principles of artistic interpretation of heroine's action, committing suicide, were found in Russian literature as early as in the late XVIII century. These principles were developed and established in the kind of debate of that era. The article describes the difference between the suicide motives of heroes by J.-W.Goethe and N. M. Karamzin, allowing us to talk about the diversity of the Russian and Western characters conduct in similar situations. For Goethe's characters, the death is a transition to a state, in which personal communication of characters becomes impossible. Therefore, their near-death communication transforms into "farewell forever". Russian heroines (novelettes of Karamzin \& Turgenev) are rapid in their decision to terminate their terrestrial life in order to accelerate their appointment with beloved after crossing over, outside of socially conditioned context. They are driven by belief in the inevitability of such appointment. Their suicide becomes not so much a way to interrupt their contacts with an imperfect world, but to speed up the appointment with their sweethearts in the other, more favorable circumstances. The authors believe that the diversity of suicide motives of Russian literary characters (Karamzin \& Turgenev) as compared with the European tradition is associated with the diversity of world perception concept, world architectonics, in which their characters commit an act. Traditional perception of this subject in the novelettes of N. M. Karamzin and I. S. Turgenev met the religious and ethical principles, predominant in Russian cultural space.
\end{abstract}

Keywords: Russian literature, comparativistics, N. M. Karamzin, J.-W. Goethe, I. S. Turgenev, novelette, character's conduct

\section{Introduction}

In Turgenev's literary heritage there are three novelettes, relating to different periods of his life, though having some narrative similarity (Muratov, 1980; Filat, 1993; Kim, 2004; Toporov, 1998). Novelettes, which are discussed below, hardly attracted the attention of researchers, and thus there is quite small number of special works, devoted to these novelettes. The interest of researchers towards them was activated in $80 \mathrm{~s}$ of the XX century and 10s of the XXI century (Ulybina, 1996; Mostovskaya, 2001; Demurova, 2006; Sen'kina, 2008; Kantor, 2014; Jockers \& Mimno, 2013).

The heroines in these novelettes commit suicide, and this event takes central place in each novelette. The basic content of these novelettes is based on the perception of other characters and the author, as a narrator, to heroine's conduct, as well as a desire to comprehend the underlying motives of such behavior. At that, storyline-forming circumstances are always the same, while motives, lying on the surface, are simple, namely unrequited love (Kuzavova, 2012). But Turgenev's novelette cast doubt concerning the simplicity of any answers. Motives of his characters' behavior can be understood only within the context of Russian literary tradition, where the suicide topic was actualized in the era of sentimentalism (Kochetkova, 1980; Paperno, 1999; Zagvazdin, 2013; Nikolaev, 1999). Features of these motives become apparent, when compared to the similar behavioral motives of European literary characters of the same era. 


\section{Materials and Methods}

As a basic research material we analyze Turgenev's novelettes "L'Antchar" (1854) (in original Russian version "Lull"), "An Unhappy Girl" (1868) and "Clara Milich (Afterlife)" (1882). In each of these novelettes suicides are accompanied by some details, not quite explainable that unwittingly cast doubt on simple interpretation of their death. Literary creations of N. M. Karamzin, J.-W. Goethe and W. Shakespeare, where the characters also commit suicide, serve the historical and literary background for conducted analysis (Table 1).

Table 1. Research materials

\begin{tabular}{ll}
\hline Authors & Titles of works \\
\hline I. S. Turgenev & L'Antchar (in original Russian version "Lull”), An Unhappy Girl, Clara Milich (Afterlife) \\
J.-W. Goethe & The Sorrows of Young Werther \\
N.M. Karamzin & Poor Liza \\
W. Shakespeare & Romeo and Juliet \\
\hline
\end{tabular}

Survey technique is determined by contemporary scientific notations about the relationship and interdependence of world conception (world architectonics), dominant in the writer's mind, and the action of his hero (Nikolaev, 2012).

\section{Results}

The heroine of "L'Antchar", shocked by departure of Veretyev from the village, died to the world, and as it seemed, slowly but surely was approaching to her terrible end. But a moment before the death (drowning), she suddenly asks to rescue her. Moreover, her death cry on rescue is mentioned twice in the novelette. For Turgenev, this circumstance is undoubtedly important detail; the detail, which somehow was given almost no considerable attention by interpreters of this Turgenev's text.

The death of the heroine of the second story, "An Unhappy Girl", is also easy to explain by beloved's betrayal and heroine's despair. However, here fairly rapid development of scenario seems to be quite strange and surprises even the hero-narrator: "... why she so soon, so irresistibly surrendered to despair, once she saw herself left? Why she did not want to wait, get to know the bitter truth from the lips of her beloved, write him a letter, at least? "(Turgenev, p. 137).

The third of noted novelettes "Clara Milich (Afterlife)" is surrounded with a mystical mist, also encourages the reader to a simple explanation of the heroine's death: despair, meaninglessness of further existence and apathy. However, the mannerism ("preciosity", as noted Aratov) and theatricality of her suicide casts doubt both in her beloved and the reader in such interpretation of her action ("She took flask with poison to the theater and drank bleach before the first act $<\ldots>$ And as soon as the curtain came down, she fell on the stage immediately ") (Turgenev, p. 109).

In all three cases the reader is persistently imposed to interpretation of heroines' suicide as the response of desperate ladies to their frustrated, unhappy love. At that, all three novelettes allude to the fact that the underlying motives of their actions are much more complex than what is laid on the surface, a simple factual knowledge.

Almost a century before mentioned Turgenev's literary experiments, literary life of Germany (as well as the whole Europe) was marked with the event, which deeply shocked the society. This was a publication of "The Sorrows of Young Werther" by Goethe, where sentimental hero commits suicide. The immediate motive for Werther's voluntary transition to better world becomes unrequited love. Nearly two decades later (in 1792) Russian writer N. M. Karamzin published his famous novelette "Poor Liza", where the fate of the heroine was perceived by reading Russian society as a higher revelation.

Some similarity in the suicide motives of the two literary heroes cannot cause any astonishment, because unrequited love was quite natural objective compliment of authors' literary attention in the era of sentimentalism, regardless of their nationality. But against this backdrop, especially significant are some essential conflicting hypotheses in the interpretation of the suicide motives of the characters of Russian and German sentimentalism.

It is interesting to note that Goethe's novelette contains a reduced scenario, which later was used a basis for the Karamzin's novelette. It is referred to an episode related to Werther's epistolary notes, dated August 12 and 
containing his dialogue with Albert. Hero recalls the story of a young lady, who was "recently pulled out of the water dead", and retells the story. Here are excerpts from this retelling: "Pretty young creature, who grew up in a narrow circle of matronly responsibilities and daily troubles $<\ldots>$ But diverse, unrevealed desires dawn in her passionate soul, while the flattery of men only encourages them $<\ldots>$ Finally, she meets a man, to whom unknown feeling irresistibly attracts her; $<\ldots>$ She forgets the world around, does not hear, does not see, does not feel anything but only him, and rushes to him the only. $<\ldots>$ Ultimately she makes a hug towards him. $<\ldots>$ She does not see the God's world around, nor those who can replace her loss, she feels herself lonely, abandoned by the whole world and, gasping in terrible hearty pain, rushes down headfirst to sink her sufferings in the death that surrounded her all round" (Goethe, pp. 51-52).

This is almost the story of Lisa, a Russian young lady, deceived in her expectations. The only difference is that Albert (Werther's interlocutor) immediately evaluates German predecessor as a "foolish girl" with "parishional outlook". It seems like Werther expects exactly this reaction, when telling Albert this story.

As for Karamzin's Lisa, nobody, except for complete cynic, can call her "foolish girl", and a girl with "parishional outlook", at least among Karamzin's contemporaries. She is "created" (represented) in a fundamentally different way than the young lady in Werther's story. The immediate motive that pushed her to suicide is fundamentally different. At a phase of rapid development of her relations with Erast, she was entirely focused on her beloved and renounce the world like the heroine of the Werther's story. "Ah! I would rather forget my soul than my dear friend! "(Russian literature of the XVIII century, 1970, 692) - admits Lisa to herself. But at the time of suicide she is driven not by despair, not by dazzle caused by the loss. More precisely, she passes through a phase of despair, when says: "I cannot live $<_{\ldots} . .>$ Oh, if the sky fell on me! Woe is me! "(Russian literature of the XVIII century, 1970, 698). But this is not the condition that becomes the immediate cause of her death. This mental state is followed by a pause ("... after a few minutes she was plunged into some reverie ..." (Russian literature of the XVIII century, 1970, 695), and then quite sober diligence was manifested in conversation with Anyuta ("Take this money to my mother, they are not stolen ... "). All this testifies to the fact that Lisa's suicide is not an act of a minute desperation, but very sensible and internally rational action. This is a deeply creative, world transformative act, and therefore not causing author's damnation. She does not run from the world, but, on the contrary, dissipates into the harmony of cultural and historical landscape, which Karamzin described in the very beginning and the end of his novelette: "... I sit lost in thought, leaning on the receptacle of Lisa's dust; pond is flowing from my eyes; leaves rustle above me" (Russian literature of the XVIII century, 1970, 695). Changed Erast, who told this story to the author a year before his own death, is another sequence that has come as a result of voluntary Lisa's death. And the last thing, the final sentence of the novelette: "Now, maybe they have reconciled!" (Russian literature of the XVIII century, 1970, 695) hints at a happy ending below the death, where dears, yet free from prejudices and misconceptions of their mortal lives, will meet together. The possibility of such a post-mortem appointment, experienced as a reward for worldly suffering, brings a fundamentally optimistic origin into the novelette.

Goethe's heroes (Werther and Lotte) sometimes are speaking about an appointment in otherness, though speaking a little differently, with a greater degree of doubt. In notes dated September 10 Lotte writes: "We will not disappear. <..> But whether we see each other again, Werther? Whether we recognize each other? What are you anticipating, what you say?" (Goethe, p. 59). Then (in September) and later, before his death (in December), Werther gives an affirmative answer: "We will not disappear! We meet again! Will see your mother! I will see, I will recognize her, and in front of her, your mother, your counterpart, I will open my soul "(Goethe, p. 115). Note we are talking about Lotte's mother, whom Werther had never seen. That is, he had to know someone, whom, in the literal sense, he would not be able to recognize.

Both Goethe's characters have no doubt concerning the verity of postulate on eternal life ("We will not disappear!", say both Lotte and Werther). Their doubt concerns just their appointment in a different world (will meet / will not meet, will recognize / will not recognize each other). This kind of doubt is not emphasized in Karamzin's novelettes. For him, apparently, unconditional are both post-mortem communication and getting to know each other. Not quite clearly is marked the question of reconciliation in the other world, but this question in Karamzin's version is solved rather positively. In his understanding, transition to another life does not concern the fundamental causes that bind the characters of the novelette. After death, they are exempt from all accidental, resulting from their existence in the social world.

The postmortem transformation of Goethe's heroes has more extensive, substantial character. The very nature of a person and, therefore, the interpersonal relations are changing. This results in a risk not to meet and get to know each other. 
Werther's foretastes of reincarnation are accompanied by his personal dissipation in the divine substance, "the communion $<\ldots>$ to the bliss of the one, who creates all in himself and from himself" (Goethe, II, 54). But if "all is created in oneself and from oneself," then the communication with other (with Lotte) after reincarnation is impossible. The thought that dreams Werther, is not a personal communication, but something else, such as a merger "in the face of the Everlasing" (Goethe, p. 115), where the spatial and temporal boundaries are erased, and the beloved and her mother appear twins, i.e. one and the same person.

That is why a significant part of Werther's text is devoted not to the anticipation of appointment, but to sentimental farewell of the hero with Lotte, farewell forever. This is something that almost lacks the text of Karamzin's novelette, which is emotionally focused on the expectation of imminent, pre-defined communication there, beyond the death.

So-called "Russian Wertheriana" allows making very interesting observations. This is a pretty large layer of Russian poetic texts of the late XVIII - early XIX centuries, described by V.M. Zhirmunsky (Zhirmunsky, 1982, pp. 41-49) and providing some insight into the perception of the Goethe's novel and Werther's character in Russian literary scene. They repeat one and the same elegiac situation: Lotte on the grave of Werther. It is suggested by Werther's suicide letter: "When on a fair summer night you ascend the mountain, recalling me, recalling how often I climbed up the valley, and then look at the cemetery on my grave, where at sunset long grass tosses in the breeze... "(Goethe, p. 104).

Only Russian poetic texts transmit a feeling of the physical presence of Werther's shadow and Lotte's desire to join him in his tomb.

One of these poems, whose author signed himself by the letter S., appeared in Karamzin's "Moscow Journal" in 1792.

$$
\begin{aligned}
& \text { Oh, you, the shadow, hovering around } \\
& \text { Deplorable places, linger on! } \\
& \text { Behold the darkness of endless suffering, } \\
& \text { Be touched by my sadness and grief! } \\
& \text { Look, oh, Werther! How Charlotte closes her days; } \\
& \text { Draws her last breath to you, } \\
& \text { Descending into your tomb! ... } \\
& \text { (Zhirmunsky, 1982, p. 46). }
\end{aligned}
$$

By happy coincidence, these verses were published in 1792 in the same $6^{\text {th }}$ issue of the "Moscow Journal" together with "Poor Liza". But they were jointed not only by the cover of the magazine, but, above all, the frame of mind and the dominants of the ideological sense. It is easy to draw a parallel between Lisa's "groan", audible in the deserted hut, and her grave, which is visited by the repentant and miserable Erast, who evidently wishes to join his beloved. Nothing of this kind is found and could have appeared in the text of Goethe's novel. Charlotte's climbing the mountain, conceivable by Werther, his recollections, glance (from there, from the mountain) casted at the cemetery, at Werther's grave, does not coincide neither with the voluminous descriptions of Russian texts, nor, most importantly, with their sense-bearing attitudes.

\section{Discussion}

Russian interpretations of post-mortem "communication" and mutual drive of Werther and Charlotte are created in the forms of their hearable, tangible, almost physical contact. Lotte perceives her beloved in a special way, as if he was dissipated in the subject and natural world; she eagers to joint him in the tomb. Poetic texts are more kin with the world outlook of Karamzin's "Poor Liza", rather than Goethe's "Werther".

Exactly the ideological grounds and artistic solutions, found by Karamzin, were dominant in the development of Russian literature in the late XVIII - early XIX century. They suited to the fullest extent to religious and ethical context, prevailing in Russia. Dominant ideas about overworld made impossible appearance of the hero, being in conflict with the world. A human, born in the bosom of the Western culture, experiencing an irreality of his inner being, is absolutely unproductive in the value system of Russian civilization. Here is obvious the formation of diverse concept of a man (Nikolaev, 1997).

"Immersion" of Karamzin's hero into the landscape descriptions corresponded to the highest degree of artistic solution to this problem. The principles, which he found in his creative work, defined in the Russian literature 
the most in-depth and historically sustainable trends. It is these trends that have found their continuation in the novelettes of I.S. Turgenev more than half a century after being identified in Karamzin's prose.

Lisa from the Karamzin's novelette and Werther from Goethe's novel are different not only in terms of their attitude to the world of Nature. They feel completely differently the uniqueness of their place in the world. This means that their suicide acts (which at first site look quite similar) are in fact significantly different in terms of the underlying motives. It is our deep conviction that the key aspect of "the immediate ethicality of the committed action" is the inner experience of the uniqueness of the place, where hero commits an action, architectonics of the world, in which the action is familiarized (Nikolaev, 2012).

"Salvation", to which the heroine of Turgenev's novelette "L'Antchar" calls and begs at the last moment of her life, does not mean literally her salvation from physical death. Apparently, cry of "salvation" meant everything, including salvation from disharmony, where she was drawn against her will. The world, in which dwelt Mariya Pavlovna, lost the balance. To some extent, it has been recovered by her death, which "has imposed on her the stamp of eternal silence and humility" (Turgenev, 4, 446). It is this perception that best suites to Turgenev's descriptions of the states of nature. In all these descriptions of nature, uniquely characterizing the state of the world as a whole, Turgenev's novelette certainly includes something going back to Karamzin's art-making techniques and philosophy, which give the true motives of heroine's suicide.

Susanna's conduct ("An Unhappy Girl") is explained by the narrator's hero. And this, certainly, is not a passionate and unrequited love to Fustov. The history of heroine in her most recent resolution is the history of her choice between Fustov and Michel, deferred just for a time. And then her pre-mortem exclamation is read with completely different sense: "He did not come!" This sounds like the key phrase to unthread the character. Narrator's response is formed in solemn and optimistic tones. He brings the reader to the idea about the continuation of the only bright moments of terrestrial life of "unhappy" heroine beyond the invisible horizon, outlined by her death: "... maybe her soul was rejoiced that she had gone to him, to her Michel?" (Turgenev, p. 137).

In all the above-mentioned Turgenev's novelettes, deep motivation of heroines' suicide is their desired appointment with beloved ones below the death; the appointment, which turns out to be impossible in the circumstances of terrestrial life. Most comprehensively this is presented in "Clara Milich" novelette, Turgenev's last story, created in the period of his artistic maturity. Conduct motives of the lead heroine do not leave room for different interpretations. After the death she starts a new and happy life that was impossible in other circumstances. That is why she approaches the death in so solemn and theatrical manner. Her poisoning, as Shakespeare's Juliet, leads the heroine not to separation, but to a merge with beloved. Parallel with Shakespeare's tragedy is built in Turgenev's novelette quite consciously and even somewhat deliberately. Aratov's kiss to Clara (after her death), obviously, repeats Romeo's dream the day before the terrible news.

In Turgenev's scene, describing mystical communication of heroes after Clara's death, we read: "He rushed to her, he wanted to kiss these smiling, these solemn lips; and he kissed them, he felt their warm touch, he even felt damp chill of her teeth ..." (Turgenev, p. 114).

In Shakespeare's tragedy:

I dreamt my lady came and found me dead; -

Strange dream, that gives a dead man leave to think, -

And breath'd such life with kisses in my lips,

That I reviv'd, and was an emperor.

(Romeo and Juliet, Act V, Scene I)

But more important for us is not a repetition of details, but just those deep, fundamental semantic differences that Turgenev suggested in his love story. For his heroes the death just eliminates visible obstacles to happiness: "Now a death does not frighten me at all. It cannot annihilate me, is it right? On the contrary, only this way and there I'll be happy ... as never was happy in life" (Turgenev, p. 115).

The Shakespearian hero does not believe in any appointment with his beloved after the death. On the contrary, his last words before poisoning are words of just last farewell:

Arms, take your last embrace! and, lips, O you

The doors of breath, seal with a righteous kiss

A dateless bargain to engrossing death! 
(Romeo and Juliet, Act V, Scene III)

Shakespearean tragedy is blame to the world that had failed to protect the great love, while Turgenev's novelette is primarily a thought of love that conquers a death (rather significant discrepancy!). This is testified by the last words of the dying hero: "But don't you know that love is stronger than death? ..." (Turgenev, p. 117).

As we have already noted, Werther, the hero of Goethe's immortal novel, says nothing about merging with the beloved Lotte below the death. In a burst of enthusiasm he sometimes dreams of his merging with the divine substance. But this is not the same thing! His novel is another sentence to the world, in which a great love is impossible.

Against the background of European predecessors (Shakespeare and Goethe), the only Karamzin speaks explicitly about the merging and reconciliation of the beloved after the death. His justification of the heroine's suicide is completely original in the concerned series of literary conceptualizations (concepts), and seems to be extremely fruitful to Russian literary history. Exactly this is confirmed, as it seems to us, by the above mentioned Turgenev's novelettes.

\section{Conclusions}

A comparison of heroes' motives allows talking about the diversity between Russian and Western characters' conduct in similar situations. The fundamental difference concerns the concept of "afterlife". Russian artistic version insists on the indispensable personal communication of sweethearts below their death. Maintenance of personal communications in a situation, where they are not burdened by the life circumstances in a socially conditioned world, is exactly the essence of the optimistic expectations in Russian novelettes. German version (Goethe) comes from other concepts of "afterlife". Here, heroes expect a profound transformation of all life forms below the death. Merging with the divine substance and dissipation in it makes it impossible for personal communication with the beloved below the death. Therefore Werther's diary takes the form of lasting farewell to his beloved before her death. Karamzin's heroine ("Poor Liza") retains the possibility of communicating with her beloved in the very act of death, as well as possibility to overcome the social constraints that made her terrestrial love impossible.

The philosophy, which in Karamzin's novelettes is rather guessed than declared, in Turgenev's "Clara Milich (Afterlife)" becomes verified action plan, a conscious act of the heroine. What is impossible in life turns into the inevitable after death? By effort of will, the heroine predetermines her life after it is interrupted due to death. Therefore, her suicide looks so solemn and theatrical.

The authors believe that the discrepancy in suicide acts of Russian literary heroes (in the novelettes of N.M. Karamzin and I.S. Turgenev) comparing with the European tradition, is associated with the specific world concept, world architectonics, in which characters commit suicide acts. A radical change of "afterlife" and the loss of customary forms and reasons for existence, characterizes the world model that has developed in the frameworks of the European tradition. In the Russian version, the death just makes corrections to the conditions of terrestrial existence, while maintaining its basic parameters. First of all, this concerns the interpersonal relation patterns between people loving each other. All this makes the underlying motives of suicide fundamentally different in terms of West European and Russian literary versions. In one case this is an exceptional desire to overcome the imperfections of terrestrial life, while in the other case heroes try to preserve all those values, which revealed themselves in the mortal life. Ideas on the suicide motives, as presented in the novelettes of N. M. Karamzin and I. S. Turgenev, met the religious and ethical principles, prevailing in the Russian cultural space.

According to the authors, the determination of the peculiarities in suicide motives of the literary characters promotes understanding of originality of artistic and anthropological type of a hero, as he had revealed himself in the classical period of the Russian literature.

\section{References}

Cantor, V. (2014). German Russophilism, or premonition of Nazism (Jewish theme in the Ivan Turgenev's novelette "An Unhappy Girl"). Retrieved August 30, 2014, from http://www.gefter.ru/archive/12406

Demurova, D. M. (2006). "L'Antchar" by I.S. Turgenev and "In the Cage" by Henry James: A Comparative Analysis. Turgenev readings, 2, 75-81. Russian Way.

Filat, T. V. (1993). Turgenev's late novelettes in the evaluation of contemporary scientists. Proceedings of the Interuniversity Scientific Conference "Problems of I.S. Turgenev's philosophy and literary method" (Devoted to 175th anniversary of the novelist). Russian Ministry of Higher Education, Pushkin House, 
Turgenev State Literary Museum, Orel.

Goethe, I.-W. (1985). Selected works in two volumes (Vol. 2).

Jockers, M. L., \& Mimno D. (2013). Significant themes in 19th-century literature. Poetics, 41(6), 750-769. http://dx.doi.org/10.1016/j.poetic.2013.08.005

Kim, S. H. (2004). A Theatrical Interpretation of Turgenev's 'Gamlet Ščigrovskogo uezda'. Russian Literature, 56(4), 413-429. http://dx.doi.org/10.1016/S0304-3479(04)00080-8

Kochetkova, N. D. (1980). Sentimentalism. Karamzin. Retrieved August 30, 2014, from http://www.feb-web.ru/feb/irl/rl0/rl1/rl1-7262.htm

Kuzavova, M. V. (2012). Lovingly-philosophical novelettes of I.S. Turgenev and the problem of cycling in writing during 1850 s (Ph.D. thesis).

Makogonenko, G. P. (1970). Russian literature of the XVIII century.

Mostovaya, N. N. (2001). "L'Antchar" is Turgenev's "Pushkin's novelette". Proceedings of the International Conference "Turgenev's two teachers: Goethe and Pushkin: poets of love" (pp. 128-133). Paris.

Muratov, A. B. (1980). Novelettes and stories of I. S. Turgenev during the period of 1867-1871 (p. 120).

Nikolaev, N. I. (1997). Human's inward in the Russian literary consciousness of the XVIII century (Ph.D. thesis). Arkhangelsk.

Nikolaev, N. I. (1999). On the question of the role of nature describing fragments in Karamzin's prose. Resphilologica: "Pushkin is our everything": Scientific notes (pp. 96-111). Arkhangelsk.

Nikolaev, N. I. (2012a). Literary hero in the world of his conduct. Journal of Scientific Publications, 3(21), 173-176.

Nikolaev, N. I. (2012b). On the question of the "literary hero" concept specification. Herald of Northern (Arctic) Federal University. A series of "Humanities and Social Sciences", 3, 100-104.

Paperno, I. (1999). Suicide as a cultural institution. Retrieved August 30, 2014, from http://www.krotov.info/libr_min/16_p/ap/rno.htm

Sen'kina, Yu. N. (2008). To the studying history of "Mystery Novels" by I.S. Turgenev. Proceedings of the Russian State Pedagogical University, 61, 230-232. Retrieved August 30, 2014, from http://www.cyberleninka.ru/article/n/k-istorii-izucheniya-tainstvennyh-povestey-is-turgeneva

Shakespeare, W. (1975). Selected Works. Leningrad, Lenizdat.

Toporov, V. N. (1998). Strange Turgenev: (Four chapters). M.: State Humanitarian University.

Turgenev, I. S. (1980a). The complete works in 30 volumes. V.10.

Turgenev, I. S. (1980b). The complete works in 30 volumes. V.4.

Turgenev, I. S. (1980c). The complete works in 30 volumes. V.8.

Ulybina, O. B. (1996). Poetics problems of "Mystery Novels" by I.S. Turgenev (Ph.D. thesis). Lobachevsly State University, Nizhniy Novgorod.

Zagvazdin, Yu. (2013). Meningitis, a Whirlpool of Death: Literary Reflections and Russian Cultural Beliefs. Progress in Brain research, 206, 35-58. http://dx.doi.org/10.1016/B978-0-444-63364-4.00019-3

Zhirmunsky, V. M. (1982). Goethe in Russian literature.

\section{Copyrights}

Copyright for this article is retained by the author(s), with first publication rights granted to the journal.

This is an open-access article distributed under the terms and conditions of the Creative Commons Attribution license (http://creativecommons.org/licenses/by/3.0/) 